\title{
Defects in Flexible Pavements: A Relationship Assessment of Defects for Low-Cost Pavement Management System
}

Shabir Hussain Khahro ( $\nabla$ shkhahro@psu.edu.sa)

Prince Sultan University https://orcid.org/0000-0002-4836-7253

Zubair Ahmed Memon

Prince Sultan University

Nur Izzi Md. Yusoff

UKM: Universiti Kebangsaan Malaysia

Lillian Gungat

UMS: Universiti Malaysia Sabah

Muhamad Razuhanafi Mat Yazid

UKM: Universiti Kebangsaan Malaysia

\section{Research Article}

Keywords: Pavement Management System, Low-cost model, Flexible pavements, Defects in flexible pavements, Developing countries

Posted Date: February 8th, 2022

DOI: https://doi.org/10.21203/rs.3.rs-1205752/v1

License: (a) (i) This work is licensed under a Creative Commons Attribution 4.0 International License. Read Full License 


\section{Abstract}

Pavement maintenance has been a key concern for any pavement management authority. Countries are facing a severe challenge of funds in maintenance schemes, especially in developing countries. The existing pavement maintenance methods are goal-specific and lack integration of various indicators that are significant for any low-cost PMS. Thus, this paper aims to investigate the possible defects which may occur in flexible pavements. It also investigates the relationship between the different defects. A detailed literature review has been done for this research to identify all possible defects in flexible pavements and key features considered in any PMS. A questionnaire was designed to seek the expert's opinion on the defects and their possible relationships to be considered for a low-cost PMS. The data was collected from 283 experts currently working in pavement management authorities and pavement maintenance schemes. Aggregated Mean Score, Box plotting and Chi-Square test are used to analyze the data. It is concluded that Bumps/Sags (3.17) are one of the major defects reported by the experts in pavements in Pakistan, followed by the fatigue cracks (3.07). Rutting (2.98) and rut depth (2.98) stand at third key defects reported in this study. Depression (2.96), potholes (2.76), longitudinal crack (2.69), edge crack (2.55), roughness (2.51) and deflection (2.50) are also regularly arising defects in pavement maintenance activities in Pakistan. The results are in the acceptance range of the three mentioned validation methods. The correlation test results show that most of the defects in structural, functional, safety and serviceability indicators reject the null hypothesis thus, there is a close relationship between these defects observed in the flexible pavements. In last stage, a PMS model is suggested to assist the road management authorities of developing countries to make low cost decision for effective pavement rehabilitation.

\section{Background}

Pavement maintenance has advanced from a notion in the 1960s to present common and practical implementation in many countries (Wu et al., 2012). Pavement maintenance management systems were well developed in different organizations around the world, but it did not take shape until the mid to late 1970 s to incorporate all these operations into a functioning PMS. The World Bank has carried out a variety of road projects since 1968 and has established many assessment modules that include models of pavement efficiency. They have been spread worldwide in over 100 countries and need to be tailored to local conditions (Thube, 2013). Due to aging, vulnerability to weather and traffic and the rising repair backlog, road transport infrastructure deteriorates. As a consequence, a primary issue is the viability of these infrastructures. The latest developments suggest that there is a substantial and growing expense of sustainable transport networks. As a result, overall thinking regarding the method of infrastructure management that takes maintenance needs into account is gaining in importance (Uddin, 2013). From 2008 to 2028, it is projected that an annual expenditure of $\$ 101$ billion would be needed to sustain all USA highways and that failure to deliver the funds will further weaken road networks (ASCE, 2013). The USA already invests over $\$ 184$ billion annually to repair and expand the road network (Congressional Budget Office, 2016). More than $£ 15$ billion is expected to be spent in England for the primary purpose of growing the potential and the current state of road networks (Transport, 2014).

The flexible pavements experience numerous distress indicators, including cracks, potholes, erosion, etc. It is not easy to identify the existence of various distress indicators. Distress position, scale, severity and mapping is a key a problem (Hosseini \& Smadi, 2021). Inspectors walking around the segment of the highway have historically carried out thorough manual checks. They are replaced by advanced distress investigation approaches owing to additional time and resources, ranging from contactless high-speed laser sensors to machines that capture video photographs of the pavement's surface (Choi, 2020). Later, processing algorithms are used to classify forms of cracks and other situations commonly focused on neural networks (Domitrović et al., 2018). Typical pavement administration faces problems such as fault classification and lengthy evaluation turnaround period (Adarkwa \& Attoh-Okine, 2013)(Shabir Hussain Khahro et al., 2021). The pavement structural capability assessment shows the pavement's residual existence, i.e., the amount of load repetitions that it can still endure. The structural capacity of a road considers the structural capacity of all road layers and the soil state of the foundation (Bejan, S.; Pérez-Acebo, 2016). A comprehensive literature review has been carried out for this study and the core summaries of the selected recent work are shown in Table 1.

\section{Table 1: Previous research work summary}




\begin{tabular}{|c|c|c|c|c|}
\hline Reference & Objective & Method & Key Achievements & Remarks \\
\hline $\begin{array}{l}\text { (Hafez et al., } \\
2021)\end{array}$ & $\begin{array}{l}\text { Identification of } \\
\text { efficient pavement } \\
\text { management } \\
\text { systems }\end{array}$ & $\begin{array}{l}\text { Case Study, } \\
\text { Survey, } \\
\text { mathematical } \\
\text { programming }\end{array}$ & $\begin{array}{l}\text { The transportation agencies can } \\
\text { determine future budget needs, } \\
\text { funding allocations and treatment } \\
\text { policy to demonstrate the best } \\
\text { possible use of pavement } \\
\text { management resources }\end{array}$ & $\begin{array}{l}\text { Fixed for local conditions and road condition } \\
\text { assessment models cannot be integrated. }\end{array}$ \\
\hline $\begin{array}{l}\text { (Hosseini \& } \\
\text { Smadi, } \\
\text { 2021) }\end{array}$ & $\begin{array}{l}\text { The accuracy of } \\
\text { prediction models } \\
\text { can affect the } \\
\text { decision-making } \\
\text { process } \\
\text { maintenance } \\
\text { activities. }\end{array}$ & $\begin{array}{l}\text { Recurrent Neural } \\
\text { Networks (RNN) } \\
\text { algorithm }\end{array}$ & $\begin{array}{l}\text { Increasing the error rate also } \\
\text { contributed to the prediction model, } \\
\text { resulting in a higher benefit reduction } \\
\text { rate. }\end{array}$ & $\begin{array}{l}\text { Focuses on the validation of the existing model. } \\
\text { It is an accuracy predication model. }\end{array}$ \\
\hline $\begin{array}{l}\text { (Momin \& } \\
\text { Hamim, } \\
\text { 2021) }\end{array}$ & $\begin{array}{l}\text { Proposed PMS for } \\
\text { Bangladesh }\end{array}$ & $\begin{array}{l}\text { Multiple } \\
\text { Regression } \\
\text { Analysis, SPSS, }\end{array}$ & $\begin{array}{l}\text { Pavement rehabilitation using } \\
\text { deflection value predicted by IRI and } \\
\text { age of pavement sections. }\end{array}$ & Limited to few defects classes only. \\
\hline $\begin{array}{l}\text { (Roberts et } \\
\text { al., 2020) }\end{array}$ & $\begin{array}{l}\text { Identification of } \\
\text { hotspot on the } \\
\text { urban road network }\end{array}$ & $\begin{array}{l}\text { Deep learning, } \\
\text { ANN, } \\
\text { Convolutional } \\
\text { Neural Networks } \\
\text { (CNN), camera } \\
\text { phone, the Google } \\
\text { Pixel 2XL }\end{array}$ & $\begin{array}{l}\text { Low-cost hotspot analysis of the } \\
\text { pavement distresses }\end{array}$ & $\begin{array}{l}\text { Needs ANN expert to process the model and } \\
\text { complex. }\end{array}$ \\
\hline $\begin{array}{l}\text { (Fani et al., } \\
2020)\end{array}$ & Developed a PMS & $\begin{array}{l}\text { Multistage } \\
\text { stochastic mixed- } \\
\text { integer } \\
\text { programming } \\
\text { model, } \\
\text { Mathematical } \\
\text { Programming }\end{array}$ & $\begin{array}{l}\text { The indices are high indicating the } \\
\text { effectiveness of the stochastic } \\
\text { solution. }\end{array}$ & $\begin{array}{l}\text { The high computational complexity of the } \\
\text { mixed-integer programming models hinders the } \\
\text { practical application of the proposed stochastic } \\
\text { pavement for large-scale networks. }\end{array}$ \\
\hline (Choi, 2020) & $\begin{array}{l}\text { Development of the } \\
\text { Road Pavement } \\
\text { Deterioration Model }\end{array}$ & $\begin{array}{l}\text { Recurrent Neural } \\
\text { Network (RNN), } \\
\text { Deep learning, GIS }\end{array}$ & $\begin{array}{l}\text { Accurate prediction of maintenance } \\
\text { timing for pavement is achieved. }\end{array}$ & $\begin{array}{l}\text { Expertise needed. A complex process, } \\
\text { equipment's needed. }\end{array}$ \\
\hline $\begin{array}{l}\text { (Obunguta \& } \\
\text { Matsushima, } \\
\text { 2020) }\end{array}$ & PMS with less data & $\begin{array}{l}\text { Markov hazard } \\
\text { model }\end{array}$ & $\begin{array}{l}\text { Examines the applicability to } \\
\text { developing countries of a PMS with } \\
\text { less data }\end{array}$ & $\begin{array}{l}\text { Needs analyses the relationship between the } \\
\text { pavement design and estimated life expectancy. }\end{array}$ \\
\hline $\begin{array}{l}\text { (Santos et } \\
\text { al., 2020) }\end{array}$ & $\begin{array}{l}\text { Selecting optimal } \\
\text { and rehabilitation } \\
\text { strategies for } \\
\text { pavements }\end{array}$ & Fuzzy logic, AHP, & $\begin{array}{l}\text { It provides decision-makers with an } \\
\text { easy and intuitive methodology for the } \\
\text { selection of pavement sections. }\end{array}$ & At network level only and complex to operate. \\
\hline $\begin{array}{l}\text { (Montoya- } \\
\text { alcaraz et } \\
\text { al., 2020) }\end{array}$ & PMS for Mexico & $\begin{array}{l}\text { Past data, Case } \\
\text { Studies, }\end{array}$ & $\begin{array}{l}\text { Developed a useful procedure that } \\
\text { allows the collection, analysis, } \\
\text { processing and updating of pavement } \\
\text { conditions data }\end{array}$ & $\begin{array}{l}\text { Limited to few defect classes. Multi Attribute } \\
\text { analysis is lacked. }\end{array}$ \\
\hline $\begin{array}{l}\text { (Engineering } \\
\text { \& Almassy, } \\
\text { 2019) }\end{array}$ & $\begin{array}{l}\text { Proposed PMS for } \\
\text { Budapest }\end{array}$ & $\begin{array}{l}\text { GIS, Pareto } \\
\text { Solution }\end{array}$ & $\begin{array}{l}\text { PMS follows an multi variable } \\
\text { optimization methods to define the } \\
\text { rehabilitation technique }\end{array}$ & $\begin{array}{l}\text { PMS system presented lacks further refinement } \\
\text { including carrying capacity results and road } \\
\text { structure. }\end{array}$ \\
\hline $\begin{array}{l}\text { (Zagvozda } \\
\text { et al., 2019) }\end{array}$ & $\begin{array}{l}\text { A database } \\
\text { management } \\
\text { system for a small } \\
\text { city }\end{array}$ & GIS, QGIS, & $\begin{array}{l}\text { GIS technologies applied to establish } \\
\text { and keep better road infrastructure } \\
\text { management. }\end{array}$ & $\begin{array}{l}\text { The database was created by a manual } \\
\text { collection of pavement condition. Their limiting } \\
\text { factor is often the price or the scope and } \\
\text { functions that do not necessarily correspond to } \\
\text { the needs of a particular road administration. }\end{array}$ \\
\hline $\begin{array}{l}\text { (Wang \& } \\
\text { Pyle, 2019) }\end{array}$ & $\begin{array}{l}\text { PaveM, PMS for the } \\
\text { California } \\
\text { Department of } \\
\text { Transportation }\end{array}$ & $\begin{array}{l}\text { Decision tree, } \mathrm{H}- \\
\text { chart, }\end{array}$ & $\begin{array}{l}\text { PaveM provides a screening of system } \\
\text { needs and total funding need } \\
\text { estimate. }\end{array}$ & $\begin{array}{l}\text { PaveM is to provide information to support } \\
\text { decision-making, and not to make decisions. }\end{array}$ \\
\hline $\begin{array}{l}\text { (Pantuso et } \\
\text { al., 2019) }\end{array}$ & $\begin{array}{l}\text { Proposed PMS for } \\
\text { Kazakhstan }\end{array}$ & $\begin{array}{l}\text { GIS, GIS web, } \\
\text { programing, }\end{array}$ & $\begin{array}{l}\text { A methodology for analyzing the } \\
\text { collected pavement data for the } \\
\text { implementation of a network-level } \\
\text { pavement management program. }\end{array}$ & $\begin{array}{l}\text { Focuses on the survey data processing. The } \\
\text { Decision-making model is linear. }\end{array}$ \\
\hline $\begin{array}{l}\text { (Santos et } \\
\text { al., 2018) }\end{array}$ & $\begin{array}{l}\text { Optimization-based } \\
\text { decision support } \\
\text { system (DSS) for } \\
\text { pavement } \\
\text { management }\end{array}$ & Pareto, Case study, & $\begin{array}{l}\text { Enhance the sustainability of the road } \\
\text { pavement maintenance decision- } \\
\text { making process by including road } \\
\text { users and environmental concerns. }\end{array}$ & $\begin{array}{l}\text { The number of objective functions referring to } \\
\text { indicators able to be simultaneously optimized } \\
\text { is limited. Cost and environmental indicators are } \\
\text { included only. }\end{array}$ \\
\hline $\begin{array}{l}\text { (Yan \& Yuan, } \\
\text { 2018) }\end{array}$ & $\begin{array}{l}\text { A low-cost video- } \\
\text { based pavement } \\
\text { distress screening } \\
\text { system }\end{array}$ & $\begin{array}{l}\text { GIS, Image } \\
\text { Sensing, }\end{array}$ & $\begin{array}{l}\text { The proposed VPADS system aims to } \\
\text { provide a computer-aided screening } \\
\text { solution for transportation authorities }\end{array}$ & $\begin{array}{l}\text { Accuracy of detecting crack and distress } \\
\text { features yielded } 80 \% \text {. Work can be further } \\
\text { expanded by developing a crowd sensing } \\
\text { inspection. Limited to image assessment only. }\end{array}$ \\
\hline (Obaidat et & Pavement distress & GIS, Paver & The system was of great help in & Limited indicators are added in the model \\
\hline
\end{tabular}

Page 3/16 


\begin{tabular}{|c|c|c|c|c|}
\hline al., 2018) & $\begin{array}{l}\text { classification and } \\
\text { maintenance } \\
\text { priorities }\end{array}$ & & $\begin{array}{l}\text { identifying, collecting and displaying } \\
\text { pavement condition data. }\end{array}$ & suggested. \\
\hline $\begin{array}{l}\text { (Domitrović } \\
\text { et al., 2018) }\end{array}$ & $\begin{array}{l}\text { Model to evaluate } \\
\text { existing pavement } \\
\text { condition }\end{array}$ & $\begin{array}{l}\text { Analytical Neural } \\
\text { Network (ANN) }\end{array}$ & $\begin{array}{l}\text { High coefficient of determination and } \\
\text { correlation between the actual data } \\
\text { and the data assessed. }\end{array}$ & $\begin{array}{l}\text { Needs ANN expert to process the model and } \\
\text { complex. }\end{array}$ \\
\hline $\begin{array}{l}\text { (Vines- } \\
\text { cavanaugh } \\
\text { et al., 2017) }\end{array}$ & StreetScan PMS & $\begin{array}{l}\text { Algorithms, } \\
\text { Decision trees and } \\
\text { mathematical } \\
\text { models, PAVER, } \\
\text { GIS }\end{array}$ & $\begin{array}{l}\text { Users are able to visualize and interact } \\
\text { with the repair suggestions and } \\
\text { condition indices }\end{array}$ & $\begin{array}{l}\text { Expertise needed. A complex process, } \\
\text { equipment's needed }\end{array}$ \\
\hline \multirow[t]{2}{*}{$\begin{array}{l}\text { (Loprencipe } \\
\text { et al., 2017) }\end{array}$} & \multirow[t]{2}{*}{ Design of a PMS } & \multirow[t]{2}{*}{$\begin{array}{l}\text { Vehicle Operating } \\
\text { Costs VOC }\end{array}$} & \multirow[t]{2}{*}{$\begin{array}{l}\text { The traffic is directly proportional to } \\
\text { the indirect user costs. }\end{array}$} & $\begin{array}{l}\text { Develop a new PMS to include the indirect } \\
\text { operating costs. }\end{array}$ \\
\hline & & & & PMS in small and mid-sized \\
\hline $\begin{array}{l}\text { (Picado- } \\
\text { Santos et al., } \\
\text { 2004) }\end{array}$ & $\begin{array}{l}\text { Proposed PMS for } \\
\text { Lisbon }\end{array}$ & $\begin{array}{l}\text { GIS, Survey, GPS, } \\
\text { VIZIROAD, Survey }\end{array}$ & $\begin{array}{l}\text { Maintenance and rehabilitation } \\
\text { decisions tends to have a more } \\
\text { reactive attitude than a planned vision. }\end{array}$ & $\begin{array}{l}\text { Such a system cannot be successfully } \\
\text { implemented without the full commitment of the } \\
\text { responsible authority and the appropriate know- } \\
\text { how of the system designer. }\end{array}$ \\
\hline $\begin{array}{l}\text { (Issa \& Abu- } \\
\text { Eisheh, } \\
\text { 2017) }\end{array}$ & $\begin{array}{l}\text { Maintenance plans } \\
\text { in Palestine }\end{array}$ & $\begin{array}{l}\text { Survey and Case } \\
\text { Study }\end{array}$ & $\begin{array}{l}\text { Operation and Maintenance manual } \\
\text { had a positive impact on the ten pilot } \\
\text { municipalities. }\end{array}$ & $\begin{array}{l}\text { Data driven and handled manually. Lacks to } \\
\text { manage large plans. }\end{array}$ \\
\hline
\end{tabular}

It is analyzed that PMS has been the topic of key research and a sufficient number of works already carried out on PMS but it is also observed that limited attempts are made on the design of low-cost PMS. Most of the PMS are designed for developed countries, whereas limited attempts are made for developing countries where the road management agencies are facing substantial financial challenges to manage the maintenance schemes for the existing road networks.

A PMS offers a comprehensive, reliable approach for choosing maintenance and rehabilitation needs and deciding goals and the optimum repair period (Donev \& Hoffmann, 2018)(Talpur et al., 2014)(Dong et al., 2021). The usefulness of every PMS depends on the data being used (Nashville-Davidson County's Transportation Plan, 2011). Primary data categories available include pavement quality scores, costs, the background of roadway building and repair, and traffic loading. Identifying and assessing pavement conditions and identifying the causes of erosion significantly emphasize every PMS (Francemensah et al., 2019). A PMS tends to eradicate human subjectivity from the equation when properly handled and to create impartial judgments. And the general efficiency of the road infrastructure is increased as the usable funds for the system are extended (Haas, 2007).

To preserve the pavement infrastructure and support its customers, a considerable effort is made every year, involving labour, money and other services (Zhang \& Mohsen, 2018). Adaptation to global climate change is projected to generate the need for a significant rise in pavement maintenance investment (Chinowsky et al., 2013)(Qiao et al., 2015). Pavement activities need to be prioritized to minimize the cost of maintenance activities and maximize the life cycle of the network (Donev \& Hoffmann, 2018). To reach this goal, a robust and accurate deterioration model is needed (Lytton, 1987). By reducing the error in deterioration models, agencies can obtain significant budget savings through timely intervention and accurate planning (George, 2000). Long-term and short-term planning that becomes possible with deterioration models is even more critical when highway agencies have limited funding (Saba, M.; Hu, 2019).

Optimization techniques used to control paving are single-goal or multi-goal optimization. There are various strategies for optimizing a single goal, such as lowering expenses or optimizing the advantages of care in terms of road conditions or life span (Irfan et al., 2012). The study on pavement maintenance is becoming an appropriate field to establish methods of multi-goal optimization. Efficient road maintenance preparation is also the primary objective of every road administration to schedule maintenance operations based on available funds (Pérez-Acebo et al., 2018). The PMS is an organized procedure to administer, sustain roadways efficiently and economically, based on statistical and quantitative methodologies. Thus, this study examines the previous work done on PMS in various countries. A critical review has been done and the gap of this study is also highlighted. It investigates the methods used for decisionmaking in various PMS. This paper also identifies all the possible defects that may occur in a flexible pavement and evaluates the relationship between the defect classes.

\section{Research Methodology}

A comprehensive process is designed for this study. As there are various stages involved in the research, a complete research flow is shown in Figure 1.

A comprehensive literature review has been made for this research and the research gap was highlighted from previous research. A review of various PMS research studies was done and its input was also considered while finalizing the list of the indicators (defects). A questionnaire was designed in the next phase to seek the expert's opinion on the defects and their priority for flexible pavement maintenance plans. The questionnaire was sent to almost 350 experts via email and hard form who are working and having experience in flexible pavement maintenance schemes. A total number of 283 questionnaires were successfully received and raw data was cleaned to observe any missing data point.

Based on the nature of the study, the data was collected from experts and professionals working in the National Highway Authority (NHA), Pakistan. The data was collected in three different rounds categorized as per study objectives. Figure 2 shows the graphical representation of the study area. 
A descriptive statistical analysis of the survey was conducted using SPSS, version 25. The response to each question in the survey was imported into SPSS from Google forms and hard form data in excel. The complete data of 283 respondents for each question was plotted in the SPSS interface. Aggregated Mean Score (AMS) was used as a data analysis approach. The AMS has been successfully used numerous times in such data sets (Kausar, 2018)(Ali et al., 2019). The result validation was a key milestone in this research; therefore, a two-tier approach was developed. Standard Deviation (SD) and Skewness \& Kurtosis tests were conducted on the data in tier one. Both validate each question separately as a distinct entity. Whereas, in tier two, the box plotting was also conducted to observe the results' possible data outliers and fitness.

A box plot, also known as a box and whisker plot, is a type of graph that displays a summary of a large amount of data in five numbers. These numbers include the median, upper quartile, lower quartile, minimum and maximum data values (Ladkin, 2018)(Whitaker et al., 2013). The use of boxplots in place of single points in a quality control chart can effectively display the information usually given in $\mathrm{X}$ and $\mathrm{R}$ charts, show the degree of compliance with specifications, and identify outliers (Iglewicz \& Hoaglin, 1987).

A boxplot is a standardized way of displaying the distribution of data based on a five-number summary ("minimum", first quartile (Q1), median, third quartile (Q3), and "maximum"). It assist in outliers identification and data grouping density (Galarnyk, 2018). A box plot is a highly visually effective way of viewing a clear summary of one or more data sets. It is beneficial for quickly summarizing and comparing different sets of results from different experiments. At a glance, a box plot allows a graphical display of the distribution of results and provides indications of symmetry within the data (Ladkin, 2018).

In the last phase, the defect relationships were analyzed using chi-square test for each primary indicator which includes; Functional Defects, Structural Defects, Safety Defects and Serviceability Defects of flexible pavements. The Chi-Square statistic is commonly used for testing relationships between categorical variables as shown in Equation 1. The null hypothesis of the Chi-Square test is that no relationship exists on the categorical variables in the population; they are independent (Statistics_Solutions, 2012)(McHugh, 2012).

$$
x_{c}^{2}=\sum \frac{\left(o_{i}-E_{i}\right)^{2}}{E_{i}}
$$

where $\mathrm{c}$ is degrees of freedom, $\mathrm{O}$ is observed value(s) and $\mathrm{E}$ is expected value(s)

This statistic can be evaluated by comparing the actual value against a critical value found in a Chi-Square distribution, but it is easier to examine the pvalue provided by SPSS simply. To conclude the hypothesis with $95 \%$ confidence, the value labeled Asymp. Sig. (which is the p-value of the Chi-Square statistic) should be less than .05 (the alpha level associated with a 95\% confidence level) (Statistics_Solutions, 2012). A low value for chi-square means there is a high correlation between two sets of data. (McHugh, 2012)(Glen, 2020).

\section{Results And Discussion}

Each indicator has been analyzed to observe the data set and the specific results of each indicator. Table 2 shows that the summary of data collected from experts for structural indicators was only considered for this study.

\section{Table 2: Case processing summary of structural indicators}

\begin{tabular}{|lllllll|}
\hline Structural Defects & \multicolumn{2}{l}{ Cases } & & & \\
& \multicolumn{2}{l}{ Valid } & & Missing & \multicolumn{2}{l|}{ Total } \\
& N & Percent & $\mathrm{N}$ & Percent & $\mathrm{N}$ & Percent \\
\hline Deflection & 283 & $100.0 \%$ & 0 & $0.0 \%$ & 283 & $100.0 \%$ \\
\hline Fatigue (Alligator) Crack & 283 & $100.0 \%$ & 0 & $0.0 \%$ & 283 & $100.0 \%$ \\
\hline Longitudinal Crack & 283 & $100.0 \%$ & 0 & $0.0 \%$ & 283 & $100.0 \%$ \\
\hline Traverse (Thermal) Crack & 283 & $100.0 \%$ & 0 & $0.0 \%$ & 283 & $100.0 \%$ \\
\hline Block Crack & 283 & $100.0 \%$ & 0 & $0.0 \%$ & 283 & $100.0 \%$ \\
\hline Swell/Frost Heaving & 283 & $100.0 \%$ & 0 & $0.0 \%$ & 283 & $100.0 \%$ \\
\hline
\end{tabular}

It can be observed that there is no missing data item and all data points of the expert's judgement are properly stored from raw data in SPSS. Raw data of each defect is carefully shifted in SPSS format to assess the results and correlations further. A separate box plot assessment is carried out in the next phase to observe the data distribution for all defects considered in the structural indicator category. Figure 4 shows the results of box plotting.

It is observed that the data is usually distributed and there is no outlier in the data set for all defects in structural indicators category. The minimum score of deflection defect is 1, whereas its maximum score is 4 given by the experts. The defection defect has major data set scores from 2 to 3 as its mean lies at score 2 at the 25 th quartile. The case of traverse cracks and block cracks is similar. Whereas, it is observed that longitudinal cracks have similar data distribution like deflection, traverse and block crack but its mean lies at 75th quartile, which is mean score 3 . The case of fatigue and swell/frost heaving is different. The minimum score of a fatigue crack is 2 whereas its major data set lies between the score of 3 to 4 with a mean score of 3 at the 25 th quartile. 
Its maximum score is 4 and its 75th quartile has the same score. In case of swell/frost heaving, its minimum score is 1 and its maximum score is 3 , which is also its 75 th quartile. Swell/frost heaving has an average mean score of 2 , which is its 25 th quartile.

Table 3 shows the summary of data collected from experts for functional indicators considered for this study.

Table 3: Case processing summary of functional indicators

\begin{tabular}{|lllllll|}
\hline Functional Defects & \multicolumn{2}{l}{ Cases } & \multicolumn{3}{ll}{$l \mid$} \\
\cline { 2 - 7 } & \multicolumn{2}{l}{ Valid } & & \multicolumn{2}{ll}{ Missing } & \multicolumn{2}{l|}{ Total } \\
\cline { 2 - 7 } & $\mathrm{N}$ & Percent & $\mathrm{N}$ & Percent & $\mathrm{N}$ & Percent \\
\hline Rutting & 283 & $100.0 \%$ & 0 & $0.0 \%$ & 283 & $100.0 \%$ \\
\hline Corrugation & 283 & $100.0 \%$ & 0 & $0.0 \%$ & 283 & $100.0 \%$ \\
\hline Shoving & 283 & $100.0 \%$ & 0 & $0.0 \%$ & 283 & $100.0 \%$ \\
\hline Potholes & 283 & $100.0 \%$ & 0 & $0.0 \%$ & 283 & $100.0 \%$ \\
\hline Patching & 283 & $100.0 \%$ & 0 & $0.0 \%$ & 283 & $100.0 \%$ \\
\hline Raveling & 283 & $100.0 \%$ & 0 & $0.0 \%$ & 283 & $100.0 \%$ \\
\hline Bleeding/Flashing & 283 & $100.0 \%$ & 0 & $0.0 \%$ & 283 & $100.0 \%$ \\
\hline Delamination & 283 & $100.0 \%$ & 0 & $0.0 \%$ & 283 & $100.0 \%$ \\
\hline Drop-off & 283 & $100.0 \%$ & 0 & $0.0 \%$ & 283 & $100.0 \%$ \\
\hline Polished Aggregates & 283 & $100.0 \%$ & 0 & $0.0 \%$ & 283 & $100.0 \%$ \\
\hline Depression & 283 & $100.0 \%$ & 0 & $0.0 \%$ & 283 & $100.0 \%$ \\
\hline Bumps/Sags & 283 & $100.0 \%$ & 0 & $0.0 \%$ & 283 & $100.0 \%$ \\
\hline
\end{tabular}

It can be observed that there is no missing data item and all data points of the expert's judgement are properly stored from raw data in SPSS. Raw data of each defect is carefully shifted in SPSS format to assess the results and correlations further. A separate box plot assessment is carried out in the next phase to observe the data distribution for all defects considered in the functional indicator category. Figure 5 shows the results of box plotting.

It is observed that the data is almost normally distributed but it has few outliers. The minimum score of rutting defects is 2 , whereas its maximum score is 4 given by the experts. The rutting defect major data set scores ranges from 2 to 4 ; therefore, its mean lies at score 3 . The case of corrugation, raveling, bleeding/flashing, delamination and drop-off is very similar. Their minimum score is 1 , which is also their 25 th quartile score and their mean score is 2 , which is also their 75th quartile score. Whereas, their maximum score is 3 , given my all experts considered in this study. Shoving defect has some variations as its data is widely and there is no specific trend of its data. There can be much reason behind this outlier. It can be an expert's misinterpretation of the defect or lack of coordination and information. Potholes and polished aggregates defects have a similar data trend as their minimum score is 1 and the maximum score is 4 , whereas their maximum data sets are between 2 to 3 , which are their scores at their 25 th and 75 th quartile. Despite such close association, it should be noted that their mean score is not similar. Pothole has higher mean score 3 as compare to polished aggregates, which have 2 mean score. Patching has different data distribution compared to all defects under functional indicators.

Patching 25th score and minimum scores are similar, whereas its 75th score and maximum score are also similar. The mean score of patching in this data set is 2 as per the data collected for this study. The defect depression has a minimum score of 2 which is also its 25 th quartile. It has a maximum score of 4 but its mean score is 3 , whereas its 75th quartile has 3.5 score. The last defect of this category is bumps/sags with a minimum score of 2 and a maximum of 4 at 75 th quartile. Its mean score is 3 but there are two outliers observed in data set for this defect. Though, in this whole data set, it is not a big percentage of outliers it's hardly $3.8 \%$ of the collected data.

\section{Table 4: Case processing summary of safety indicators}

\begin{tabular}{|lllllll|}
\hline & \multicolumn{3}{l}{ Cases } & & & \\
& \multicolumn{2}{l}{ Valid } & & \multicolumn{2}{l|}{ Missing } & \multicolumn{2}{l|}{ Total } & \\
& $\mathrm{N}$ & Percent & $\mathrm{N}$ & Percent & $\mathrm{N}$ & Percent \\
\hline Skid Resistance & 283 & $100.0 \%$ & 0 & $0.0 \%$ & 283 & $100.0 \%$ \\
\hline Potholes & 283 & $100.0 \%$ & 0 & $0.0 \%$ & 283 & $100.0 \%$ \\
\hline Edge Crack & 283 & $100.0 \%$ & 0 & $0.0 \%$ & 283 & $100.0 \%$ \\
\hline Rut Depth & 283 & $100.0 \%$ & 0 & $0.0 \%$ & 283 & $100.0 \%$ \\
\hline Rail Road Crossing & 283 & $100.0 \%$ & 0 & $0.0 \%$ & 283 & $100.0 \%$ \\
\hline
\end{tabular}


It can be observed that there is no missing data item and all data points of the expert's judgement are properly stored from raw data in SPSS. Raw data of each defect is carefully shifted in SPSS format to assess the results and correlations further. A separate box plot assessment is carried out in the next phase to observe the data distribution for all defects considered in the safety indicator category. Figure 6 shows the results of box plotting.

It is observed that the data on defects in safety indicators varies for each defect. There is one defect with an outlier. The minimum score of skid resistance is 1 , which is also its 25 th quartile and its maximum score is 3 . The mean score of skid resistance defect is 2 , which is also its 75 th quartile. The potholes minimum score is 1 , and its maximum score is 4 , whereas its mean score is 2 , which is also its 25 th quartile. The minimum score, 25 th quartile and mean score of edge crack is 2 , whereas its maximum score is 4 . The rut depths 1 , whereas its maximum score is 4 given by the experts. The defection defect has major data set scores from 2 to 3 as its mean lies at score 2 at 25th quartile. The case of traverse cracks and block crack is similar. Whereas, it is observed that longitudinal cracks have similar data distribution like deflection, traverse and block crack but its mean lies at 75th quartile which is mean score 3 . The case of fatigue and swell/frost heaving is different. The minimum score of a fatigue crack is 2 , whereas its major data set lies between the score of 3 to 4 with a mean score of 3 at the 25th quartile. Its maximum score is 4 , and its 75 th quartile has the same score. In the case of swell/frost heaving, its minimum score is 1 and its maximum score is 3 , which is also its 75 th quartile. Swell/frost heaving has an average mean score of 2 , which is its 25 th quartile.

Table 5 shows the summary of data collected from experts for serviceability indicators considered for this study.

\section{Table 5: Case processing summary of serviceability indicators}

\begin{tabular}{|lllllll|}
\hline & \multicolumn{2}{l}{ Cases } & & & & \\
& \multicolumn{2}{l}{ Valid } & & \multicolumn{2}{ll}{ Missing } & \multicolumn{2}{l|}{ Total } & \\
\cline { 2 - 7 } & $\mathrm{N}$ & Percent & $\mathrm{N}$ & Percent & $\mathrm{N}$ & Percent \\
\hline Roughness & 283 & $100.0 \%$ & 0 & $0.0 \%$ & 283 & $100.0 \%$ \\
\hline Slippage Crack & 283 & $100.0 \%$ & 0 & $0.0 \%$ & 283 & $100.0 \%$ \\
\hline Reflection Crack & 283 & $100.0 \%$ & 0 & $0.0 \%$ & 283 & $100.0 \%$ \\
\hline Draining & 283 & $100.0 \%$ & 0 & $0.0 \%$ & 283 & $100.0 \%$ \\
\hline
\end{tabular}

It can be observed that there is no missing data item and all data points of the expert's judgement are properly stored from raw data in SPSS. Raw data of each defect is carefully shifted in SPSS format to assess the results and correlations further. A separate box plot assessment is carried out in the next phase to observe the data distribution for all defects considered in the serviceability indicator category. Figure 7 shows the results of box plotting.

Any PMS must explore the frequent defects and problems pavement is suffering from; therefore, defect identification is done and prioritize the key defects after the expert's opinion. Table 6 shows the ranking of the defects typically observed in the flexible pavements.

Table 6: Ranking of all flexible pavement defects 


\begin{tabular}{|c|c|c|c|c|c|}
\hline & Statistic & Statistic & Skewness & Kurtosis & Ranking \\
\hline Defects & Mean & Std. Deviation & Statistic & Statistic & \\
\hline Bumps/Sags & 3.1731 & 0.7598 & -0.863 & 0.952 & 1 \\
\hline Fatigue (Alligator) Crack & 3.0769 & 0.73688 & -0.123 & -1.108 & 2 \\
\hline Rutting & 2.9808 & 0.75382 & 0.032 & -1.205 & 3 \\
\hline Rut Depth & 2.9808 & 0.72735 & 0.03 & -1.058 & 3 \\
\hline Depression & 2.9615 & 0.73994 & 0.062 & -1.129 & 4 \\
\hline Potholes & 2.7692 & 0.83114 & 0.037 & -0.802 & 5 \\
\hline Longitudinal Crack & 2.6923 & 0.80534 & 0.158 & -0.682 & 6 \\
\hline Edge Crack & 2.5577 & 0.69771 & 0.867 & -0.447 & 7 \\
\hline Roughness & 2.5192 & 0.72735 & 0.408 & -0.222 & 8 \\
\hline Deflection & 2.5 & 0.93934 & 0.148 & -0.826 & 9 \\
\hline Polished Aggregates & 2.4615 & 0.82751 & 0.235 & -0.412 & 10 \\
\hline Traverse (Thermal) Crack & 2.4038 & 0.7478 & 0.05 & -0.218 & 11 \\
\hline Block Crack & 2.3077 & 0.64286 & 0.079 & -0.048 & 12 \\
\hline Potholes & 2.2692 & 1.01199 & 0.488 & -0.781 & 13 \\
\hline Draining & 2.1154 & 0.70444 & -0.166 & -0.92 & 14 \\
\hline Swell/Frost Heaving & 2.0962 & 0.7478 & -0.16 & -1.162 & 15 \\
\hline Shoving & 2 & 0.68599 & 0 & -0.794 & 16 \\
\hline Patching & 1.9615 & 0.79117 & 0.069 & -1.385 & 17 \\
\hline Drop-off & 1.9038 & 0.7211 & 0.147 & -1.018 & 18 \\
\hline Slippage Crack & 1.8846 & 0.70444 & 0.166 & -0.92 & 19 \\
\hline Raveling & 1.8077 & 0.71506 & 0.302 & -0.965 & 20 \\
\hline Bleeding/Flashing & 1.7692 & 0.67491 & 0.313 & -0.762 & 21 \\
\hline Reflection Crack & 1.7692 & 0.70336 & 0.358 & -0.893 & 21 \\
\hline Delamination & 1.7115 & 0.66676 & 0.404 & -0.719 & 22 \\
\hline Skid Resistance & 1.6731 & 0.67798 & 0.511 & -0.723 & 23 \\
\hline Corrugation & 1.6346 & 0.62713 & 0.457 & -0.607 & 24 \\
\hline Rail Road Crossing & 0.2308 & 0.42544 & 1.316 & -0.28 & 25 \\
\hline
\end{tabular}

It has been observed that Bumps/ Sags are one of the major defects reported by the experts in pavements in Pakistan, followed by fatigue cracks. Rutting and rut depth stands at the third key defects reported in this study. Depression, potholes, longitudinal crack, edge crack, roughness and deflection are also regularly arising defects in pavement maintenance activities in Pakistan. Similar defect ranking were also observed in the previous studies (Rashid \& Gupta, 2017)(Public, 2017)(Loprencipe \& Pantuso, 2017)(Gáspár, 2017)(Van Geem et al., 2016).The result validation is done using standard deviation, skewness and kurtosis test. Most of the results are in the acceptance range of the three mentioned validation methods. It is analyzed that skid resistance, corrugation, and railroad crossing are rare types of defects in flexible pavements.

In the later phase, it was essential to analyze the possible relationship between the defects considered under four PMS indicators. It is crucial to observe that "Is there any close relation occur or do not occur between the defects" considered under all indicators for this PMS. So, the Chi-Square test is conducted to assess the relationship between the defects for flexible pavements. Table 7 shows the results of the test.

\section{Table 7: Chi-Square test results}




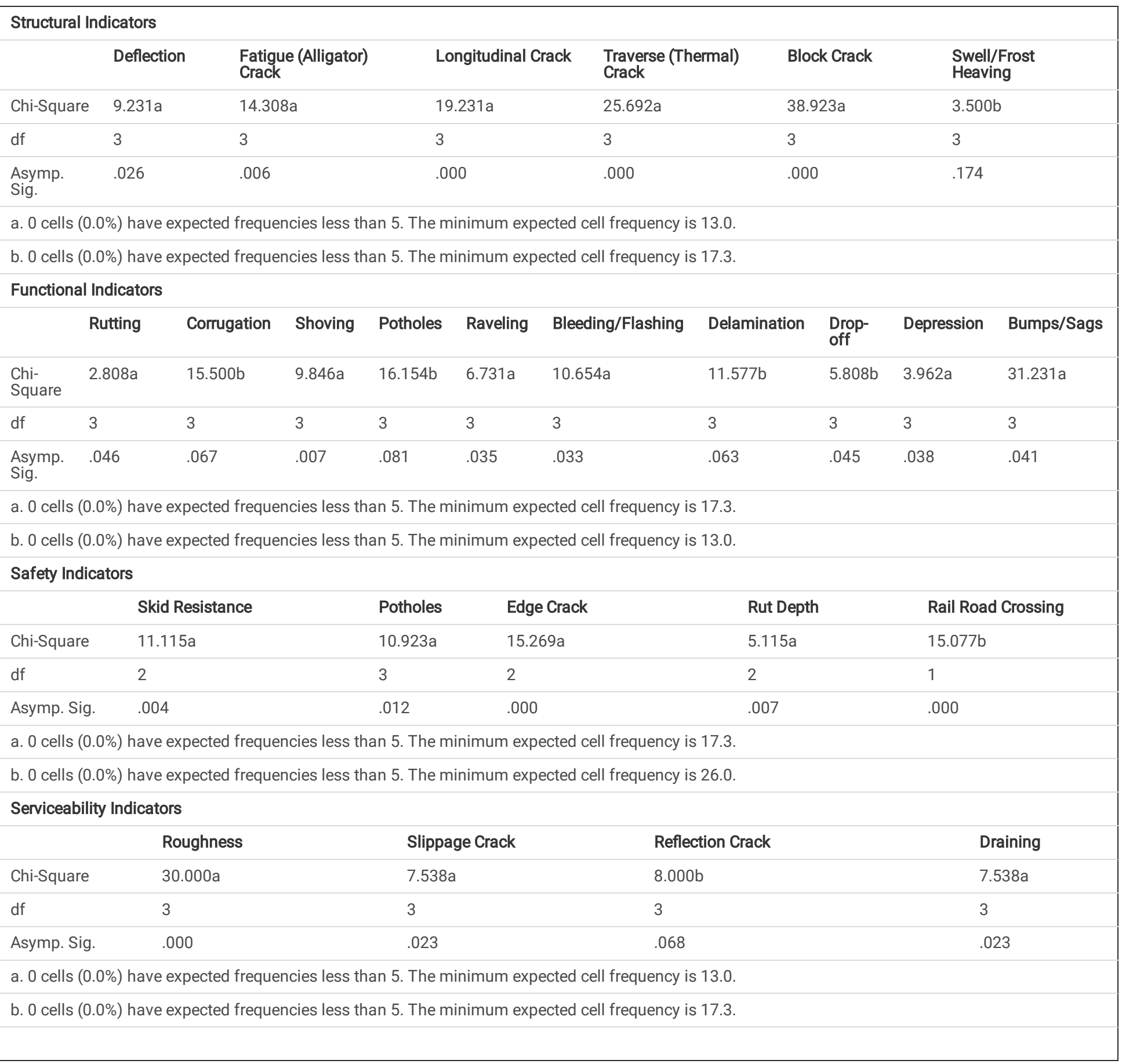

The correlation test results of structural indicators show that the defection, fatigue crack, longitudinal crack, traverse crack and block cracks rejects the null hypothesis thus, there is a close relationship between these defects in flexible pavements. There are possible chances that where deflection is observed in flexible pavements, there can also be fatigue crack, longitudinal crack, traverse crack, and block cracks. A similar relationship is also possible between these defects, which rejects the null hypotheses. Whereas, only frost heaving has no relationship observed between the defect types in structural indicator of the flexible pavement's maintenance management. The correlation test results of functional indicators show that rutting, shoving, raveling, bleeding, depression and bumps rejects the null hypothesis and there is a close relationship between these defects There are possible chances that where rutting is observed, there can also be shoving, raveling, bleeding, depression, and bumps. Whereas, corrugation, potholes, delamination and drop off has no relationship observed between the defect types in functional indicator.

Similarly, safety indicators including skid resistance, potholes, edge crack and rut depth reject the null hypothesis. Hence, there is a close relationship between these defects There are possible chances that where skid resistance is observed then there can also be potholes, edge crack and rut depth. The serviceability indicators show that roughness, slippage crack and poor drainage reject the null hypothesis so, there is a close relationship between these defects There are possible chances that where roughness is observed in flexible pavements, then there can also be slippage crack and poor drainage.

In the end based on the results of the study, a PMS framework is proposed for developing countries as shown in figure 8. 
The proposed PMS has three tier decision making approach. In tier one, the case selection is made. There can be possible three cases for any pavement maintenance scheme which includes; Emergency Case (Need based, Non predictable), Routine Case (Short term plans, require less time, efforts and funds) and Periodic Case (Long term plans, require more time, efforts and funds). Each case has its own implications and significance. Therefore, this framework will select the case first. In second tier, the indicators will be selected based on the feedback of tier one. Like for emergency case, road safety indicators have top most priority followed for functional and serviceability indicators as part of the similar suggestion is given by previous studies (Shabir Hussain Khahro et al., 2021)(Ding et al., 2013)(Heyns et al., 2012)(Manosalvas-Paredes et al., 2020)(Hamim et al., 2021). Similarly, the indicator selection for other cases is different as shown in the framework. In the third tier, the model will select the sub-indicators based on the second-tier results. Like for safety the sub indicators are different and the sub indicators will be selected based on their score. The sub-indicators are classified based on their scores in the expert's feedback as shown in the Table 6 above. In class one sub indicator category, the defects with score more than 3 will be selected by the model. It is based on frequency and significance of the defect as per the scenario rated by the experts. Likewise, the defects with score between 2.5 to 3.0 are classified as class two. There are different defects which lie in class two as shown in the framework. In class three sub indicator category, the defects with score between 2.0 and 2.5 will be selected and the defects with score below 2.0 will be classified as last category by the model.

The model will group the tiers based on the different scenario required by the pavement maintenance management authority. The model will optimize the decision based on pavement defect type, its frequency and low-cost solution.

\section{Conclusion}

It is concluded that PMS has been the topic of key interest but limited attempts are made for low-cost PMS globally and none of such attempts made earlier in Pakistan where existing models cannot work efficiently due to varying local conditions. GIS is mainly used for graphical representation of the pavement maintenances schemes with the combination of surveys, case studies, machine learning, deep learning, SPSS and PLS as a decision-making tool for PMS indicators. Whereas limited attempts are made using PLS.

It is concluded that Bumps/Sags (3.17) are one of the major defect reported by the experts in pavements in Pakistan followed by the fatigue cracks (3.07). Rutting (2.98) and rut depth (2.98) stand at third key defects reported in this study. Depression (2.96), potholes (2.76), longitudinal crack (2.69), edge crack (2.55), roughness (2.51) and deflection (2.50) are also regularly arising defects in pavement maintenance activities in Pakistan.

The correlation test of structural indicators shows that the defection, fatigue crack, longitudinal crack, traverse crack and block cracks reject the null hypothesis thus, there is a close relationship between these defects in flexible pavements. There are possible chances that where deflection is observed in flexible pavements, there can also be fatigue crack, longitudinal crack, traverse crack, and block cracks. Similarly, the correlation test of functional indicators shows that rutting, shoving, raveling, bleeding, depression and bumps reject the null hypothesis under one category thus, there is a close relationship between these defects in flexible pavements.

The correlation test of safety indicators shows that skid resistance, potholes, edge crack and rut depth reject the null hypothesis under one category thus, there is a close relationship between these defects in flexible pavements. Likewise, the correlation test of serviceability indicators shows that roughness, slippage crack and poor drainage reject the null hypothesis thus, there is a close relationship between these defects in flexible pavements.

The proposed model works in three stages including case selection, indicator selection followed by sub indicator selection. Each case represents a different real practical scenario and cost is the key feature in defect selection criteria and its possible treatment selection. The model has simple operating method which is user friendly and limited numeric calculations are involved in the model. This model will assist the decision makers of pavement maintenance authorities to make condition-based decision and utilizing limited funds they can assure the functionality and serviceability of the road for the users.

The model can also be used for rigid pavement with some modification in the sub indicators only whereas the cases and indicators can be same for both classes of pavements. The model can be extended to any mobile application for easy and rapid decision making for the users.

\section{Declarations}

\section{Acknowledgment:}

The authors are thankful to respondents for sharing their experience without their feedback it was not possible to complete this study.

\section{Ethical Approval}

Not applicable.

\section{Consent to participate}

Not applicable.

\section{Consent to Publish}

Not applicable.

\section{Authors Contributions}


Shabir Hussain Khahro: Conceptualization, Data Collection, and Analysis, Writing

Zubair Ahmed Memon: Project Administration

Nur Izzi Md. Yusoff: Supervisor and Review

Lillian Gungat: Research methodology and data collection

Muhamad Razuhanafi Mat Yazid: Questionnaire design and validation

Funding statement

NA

\section{Conflict of Interest}

The authors declare that there is no conflict of interest.

\section{Availability of data and material}

Not applicable.

\section{References}

1. Adarkwa OA, Attoh-Okine N (2013) Pavement crack classification based on tensor factorization. Constr Build Mater 48:853-857. https://doi.org/10.1016/j.conbuildmat.2013.07.091

2. Ali TH, Akhund MA, Memon NA, Memon AH, Imad HU, Khahro SH (2019) Application of Artifical Intelligence in Construction Waste Management. Proceedings of 2019 8th International Conference on Industrial Technology and Management, ICITM 2019, 50-55.

https://doi.org/10.1109/ICITM.2019.8710680

3. ASCE (2013) Report Card for America's Infrastructure. American Society of Civil Engineers. https://ascelibrary.org/doi/pdf/10.1061/9780784478837

4. Bejan S, Pérez-Acebo H (2016) Modeling the dynamic interaction between a vibratory-compactor and ground. Romanian Journal of Acoustics and Vibration 12:94-97

5. Chinowsky PS, Price JC, Neumann JE (2013) Assessment of climate change adaptation costs for the U.S. road network. Glob Environ Change 23(4):764-773. https://doi.org/10.1016/j.gloenvcha.2013.03.004

6. Choi S (2020) Development of the Road Pavement Deterioration Model Based on the Deep Learning Method

7. Congressional Budget Office (2016) Approaches to Make Federal Highway Spending More Productive (Issue February). https://doi.org/10.1080/0143659042000174860

8. Ding T, Sun L, Chen Z (2013) Optimal Strategy of Pavement Preventive Maintenance Considering Life-cycle Cost Analysis. Procedia - Social and Behavioral Sciences 96(Cictp):1679-1685. https://doi.org/10.1016/j.sbspro.2013.08.190

9. Domitrović J, Dragovan H, Rukavina T, Dimter S (2018) Application of an artificial neural network in pavement management system. Tehnicki Vjesnik 25:466-473. https://doi.org/10.17559/TV-20150608121810

10. Donev V, Hoffmann M (2018) Optimisation of pavement maintenance and rehabilitation activities, timing and work zones for short survey sections and multiple distress types zones for short survey sections and multiple distress types. Int J Pavement Eng 1-25.

https://doi.org/10.1080/10298436.2018.1502433

11. Dong J, Meng W, Liu Y, Ti J (2021) A framework of pavement management system based on loT and big data. Advanced Engineering Informatics, 47(November 2020), 101226. https://doi.org/10.1016/j.aei.2020.101226

12. Engineering C, Almassy K (2019) Optimization Methods of the Pavement Management System of Budapest. Journal of Civil Engineering and Management 25(8):798-804

13. Fani A, Golroo A, Mirhassani A, Gandomi AH (2020) Pavement maintenance and rehabilitation planning optimisation under budget and pavement deterioration uncertainty. Int J Pavement Eng 0(0):1-11. https://doi.org/10.1080/10298436.2020.1748628

14. France-mensah J, Asce SM, Brien WJO, Ph D, Asce M (2019) Developing a Sustainable Pavement Management Plan: Tradeoffs in Road Condition, User Costs, and Greenhouse Gas Emissions. Journal of Management Engineering 35(3):1-13. https://doi.org/10.1061/(ASCE)ME.1943-5479.0000686

15. Galarnyk M (2018) Understanding Boxplots. Towardsdatascience.Com. https://towardsdatascience.com/understanding-boxplots-5e2df7bcbd51

16. Gáspár L (2017) Management aspects of road pavement rehabilitation. Gradjevinar 69(1):31-40. https://doi.org/10.14256/JCE.1629.2016

17. George K (2000) MDOT Pavement Management System: Prediction Models and Feedback System. Mississippi Department of Transportation, Jackson, MS, USA

18. Glen S (2020) Chi-Square Statistic: How to Calculate It / Distribution. StatisticsHowTo.Com: Elementary Statistics for the Rest of Us! https://www.statisticshowto.com/probability-and-statistics/chi-square/

19. Haas R (2007) Future of pavement management systems. Natioanl Pavement Management Conference 
20. Hafez M, Ksaibati K, Atadero R (2021) Pavement maintenance practices of low-volume roads and potential enhancement: the regional experience of Colorado pavement management system. Int J Pavement Eng 22(6):718-731. https://doi.org/10.1080/10298436.2019.1643021

21. Hamim OF, Aninda SS, Hoque MS, Hadiuzzaman M (2021) Suitability of pavement type for developing countries from an economic perspective using life cycle cost analysis. International Journal of Pavement Research and Technology 14(3):259-266. https://doi.org/10.1007/s42947-020-0107-z

22. Heyns T, Heyns PS, De Villiers JP (2012) A method for real-time condition monitoring of haul roads based on Bayesian parameter estimation. J Terrramech 49(2):103-113. https://doi.org/10.1016/j.jterra.2011.12.001

23. Hosseini SA, Smadi O (2021) How Prediction Accuracy Can Affect the Decision-Making Process in Pavement Management System. Infrastructures 6(28):1-17

24. Iglewicz B, Hoaglin DC (1987) Use of Boxplots for Process Evaluation. Journal of Quality Technology 19(4):180-190. https://doi.org/10.1080/00224065.1987.11979063

25. Irfan M, Khurshid MB, Bai Q, Labi S, Morin TL (2012) Establishing optimal project-level strategies for pavement maintenance and rehabilitation - A framework and case study. Eng Optim 44(5):565-589. https://doi.org/10.1080/0305215X.2011.588226

26. Issa A, Abu-Eisheh S (2017) Evaluation of implementation of municipal roads' maintenance plans in Palestine: A pilot case study. International Journal of Pavement Research and Technology 10(5):454-463. https://doi.org/10.1016/j.jprt.2017.07.006

27. Kausar MHN (2018) The Correlation Between Presence And Average Means Score In Intermediate Of Mathematics Class. Pakistan Journal of Society, Education and Language (PJSEL), 4(2), 14-27

28. Ladkin A (2018) Advantages \& Disadvantages of a Box Plot. Sciencing. https://sciencing.com/advantages-disadvantages-box-plot-12025269.html

29. Loprencipe G, Pantuso A (2017) A specified procedure for distress identification and assessment for urban road surfaces based on PCl. Coatings 7(5). https://doi.org/10.3390/coatings7050065

30. Loprencipe G, Pantuso A, Di Mascio P (2017) Sustainable Pavement Management System in Urban Areas Considering the Vehicle Operating Costs. Sustainability (Switzerland) 9(3). https://doi.org/10.3390/su9030453

31. Lytton RL (1987) Concepts of Pavement Performance Prediction and Modeling. 2nd North American Conference on Managing Pavements, Toronto, ON, Canada

32. Manosalvas-Paredes M, Roberts R, Barriera M, Mantalovas K (2020) Towards more sustainable pavement management practices using embedded sensor technologies. Infrastructures 5(1). https://doi.org/10.3390/infrastructures5010004

33. McHugh ML (2012) The Chi-square test of independence. Biochemia Medica 23(2):143-149. https://doi.org/10.11613/BM.2013.018

34. Momin K, Al, Hamim OF (2021) Pavement Management System Using Deflection Prediction Model of Flexible Pavements In Bangladesh. 5th International Conference on Advances in Civil Engineering (ICACE 2020), 171-176

35. Montoya-alcaraz M, Mungaray-moctezuma A, Garc L (2020) Sustainable Road Maintenance Planning in Developing Countries Based on Pavement Management Systems: Case Study in Baja California, M é xico. Sustainability 12(36):1-14

36. Nashville-Davidson County's Transportation Plan (2011)Metropolitan Planning Commission

37. Obaidat MT, Ghuzlan KA, Al-mestarehi BW (2018) Integration of Geographic Information System (GIS) and PAVER System Toward Efficient Pavement Maintenance Management System (PMMS) Integration of Geographic Information System (GIS) and PAVER System Toward Efficient Pavement Maintenance Management S. Jordan Journal of Civil Engineering 12(3):449-462

38. Obunguta F, Matsushima K (2020) Optimal pavement management strategy development with a stochastic model and its practical application to Ugandan national roads. Int J Pavement Eng. https://doi.org/10.1080/10298436.2020.1857759

39. Pantuso A, Loprencipe G, Bonin G, Teltayev BB (2019) Analysis of pavement condition survey data for effective implementation of a network level pavement management program for Kazakhstan. Sustainability (Switzerland) 11(3). https://doi.org/10.3390/su11030901

40. Pérez-Acebo H, Linares-Unamunzaga A, Abejón R, Rojí E (2018) Research Trends in Pavement Management during the First Years of the 21st Century: A Bibliometric Analysis during the 2000-2013 Period. Applied Sciences 8(7):1041. https://doi.org/10.3390/app8071041

41. Picado-Santos L, Ferreira A, Antunes A, Carvalheira C, Santos B, Bicho M, Quadrado I, Silvestre S (2004) Pavement management system for Lisbon. Municipal Engineer 157(3):157-165. https://doi.org/10.1680/muen.157.3.157.49462

42. Public MOF (2017)Guidelines for Repairing Defects of Roads

43. Qiao Y, Dawson AR, Parry T, Flintsch GW (2015) Evaluating the effects of climate change on road maintenance intervention strategies and Life-Cycle Costs. Transportation Research Part D: Transport and Environment 41:492-503. https://doi.org/10.1016/j.trd.2015.09.019

44. Rashid Z, Bin, Gupta R (2017) Study of Defects in Flexible Pavement and Its Maintenance. International Journal of Recent Engineering Research and Development (IJRERD) 2(6):30-37

45. Roberts R, Giancontieri G, Inzerillo L, Di Mino G (2020) Towards low-cost pavement condition health monitoring and analysis using deep learning. Applied Sciences (Switzerland) 10(1). https://doi.org/10.3390/app10010319

46. Saba M, Hu GP (2019) Predicting Metropolitan Crime Rates Using Machine Learning Techniques. Smart Service Systems, Operations Management, and Analytics. INFORMS International Conference on Service Science, Nanjing, China, 77-86

47. Santos J, Ferreira A, Flintsch G, Cerezo V (2018) A multi-objective optimisation approach for sustainable pavement management. Struct Infrastruct Eng 14(7):854-868. https://doi.org/10.1080/15732479.2018.1436571

48. Santos J, Torres-Machi C, Morillas S, Cerezo V (2020) A fuzzy logic expert system for selecting optimal and sustainable life cycle maintenance and rehabilitation strategies for road pavements. Int J Pavement Eng 0(0):1-13. https://doi.org/10.1080/10298436.2020.1751161

Page $12 / 16$ 
49. Shabir Hussain K et al (2021) Low-Cost Pavement Management System for Developing Countries.Sustainability, 13(11)

50. Statistics_Solutions (2012) Using Chi-Square Statistic in Research - Statistics Solutions. Statisticssolution. http://www.statisticssolutions.com/usingchi-square-statistic-in-research/

51. Talpur MAH, Napiah M, Chandio IA, Qureshi TA, Khahro SH (2014) Development of a regional transport policy support system for rural planning agencies in developing world. Procedia Eng 77:2-10. https://doi.org/10.1016/j.proeng.2014.07.003

52. Thube DT (2013) Highway Development and Management Model (HDM-4): Calibration and adoption for low-volume roads in local conditions. Int J Pavement Eng 14(1):50-59. https://doi.org/10.1080/10298436.2011.606320

53. Transport UD (2014) for. UK Government: Biggest upgrade to roads in a generation

54. Uddin W (2013) Public Infrastructure Asset Management. 157

55. Van Geem C, Bellen M, Bogaerts B, Beusen B, Berlémont B, Denys T, De Meulenaere P, Mertens L, Hellinckx P (2016) Sensors on Vehicles (SENSOVO) Proof-of-concept for Road Surface Distress Detection with Wheel Accelerations and ToF Camera Data Collected by a Fleet of Ordinary Vehicles. Transportation Research Procedia 14:2966-2975. https://doi.org/10.1016/j.trpro.2016.05.419

56. Vines-cavanaugh D, Shamsabadi SS, Zhao Y, Huang G (2017) City-Wide Application of the Affordable and Rapid StreetScan Pavement-Management System. J Infrastruct Syst 23(2). https://doi.org/10.1061/(ASCE)IS.1943-555X.0000333

57. Wang Z, Pyle T (2019) Implementing a pavement management system: The Caltrans experience. Int J Transp Sci Technol 8(3):251-262. https://doi.org/10.1016/j.ijtst.2019.02.002

58. Whitaker RT, Mirzargar M, Kirby RM (2013) Contour boxplots: A method for characterizing uncertainty in feature sets from simulation ensembles. IEEE Trans Vis Comput Graph 19(12):2713-2722. https://doi.org/10.1109/TVCG.2013.143

59. Wu Z, Flintsch G, Ferreira A, de Picado-Santos L (2012) Framework for Multiobjective Optimization of Physical Highway Assets Investments. Journal of Transportation Engineering 138(12):1411-1421. https://doi.org/10.1061/(ASCE)TE.1943-5436.0000458

60. Yan WY, Yuan X (2018) A low-cost video-based pavement distress screening system for low-volume roads. Journal of Intelligent Transportation Systems 0(0):1-14. https://doi.org/10.1080/15472450.2017.1366320

61. Zagvozda M, Dimter S, Moser V, Barišić I (2019) Application of GIS technology in Pavement Management Systems. Gradjevinar 71(4):297-304. https://doi.org/10.14256/JCE.1980.2017

62. Zhang Y, Mohsen JP (2018) A Project-Based Sustainability Rating Tool for Pavement Maintenance. Engineering 4(2):200-208. https://doi.org/10.1016/j.eng.2018.03.001

\section{Figures}




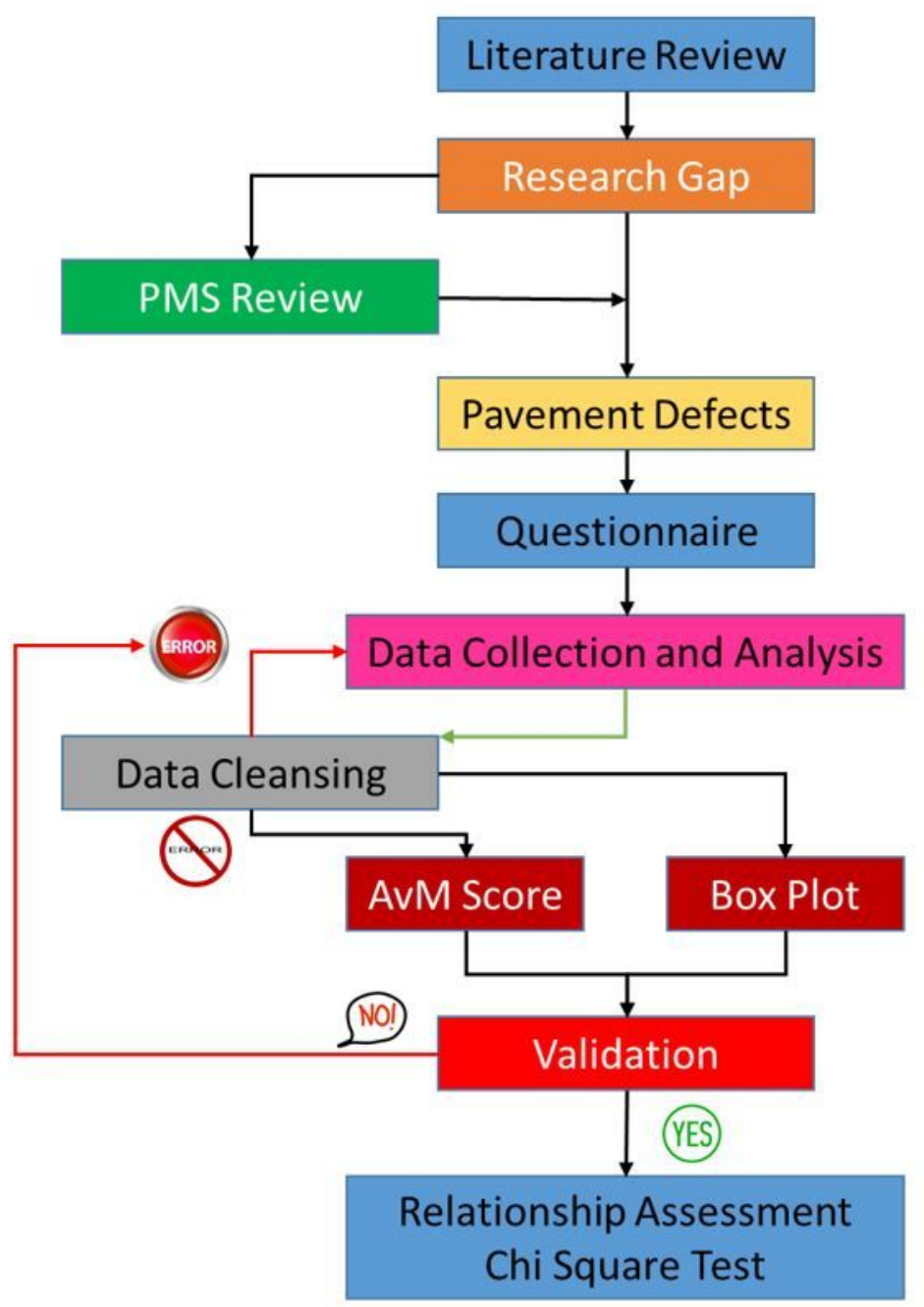

Figure 1

Research methodology

\section{MAP OF}

NATIONAL HIGHWAY NETWORK

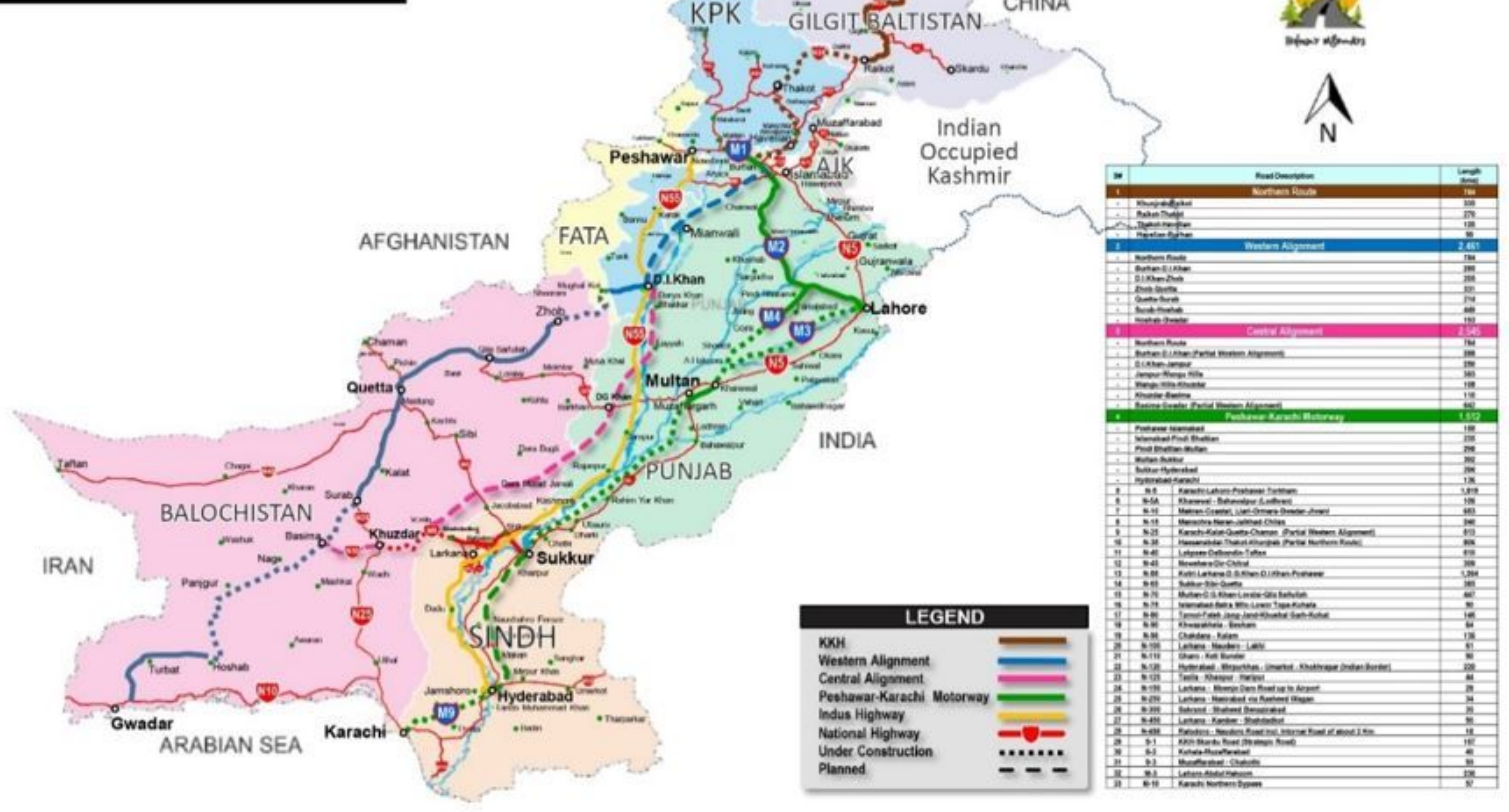


Figure 2

National Highway Network in Pakistan

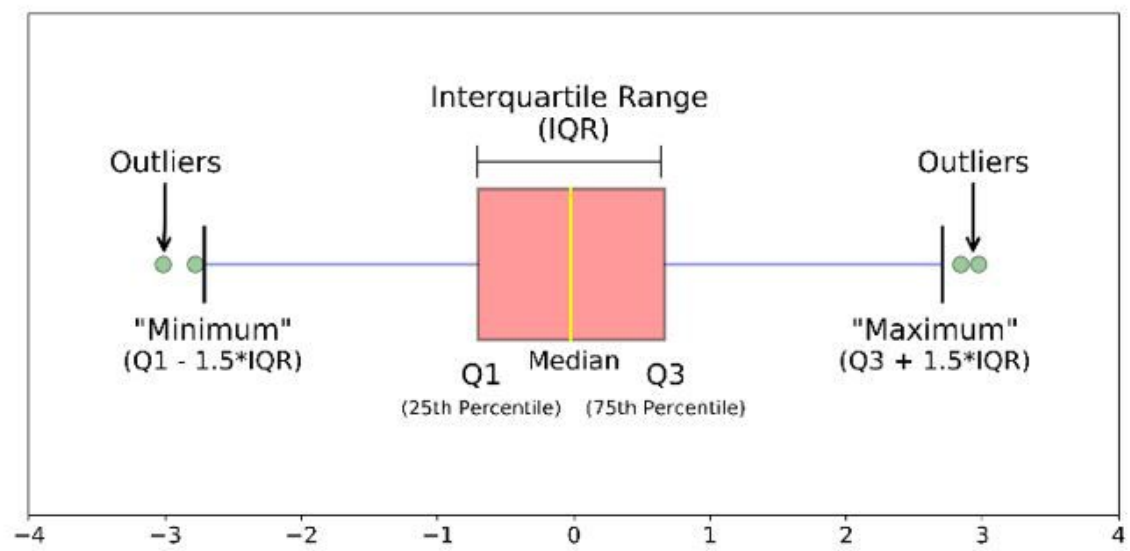

Figure 3

Box plot and its structure (Iglewicz \& Hoaglin, 1987)

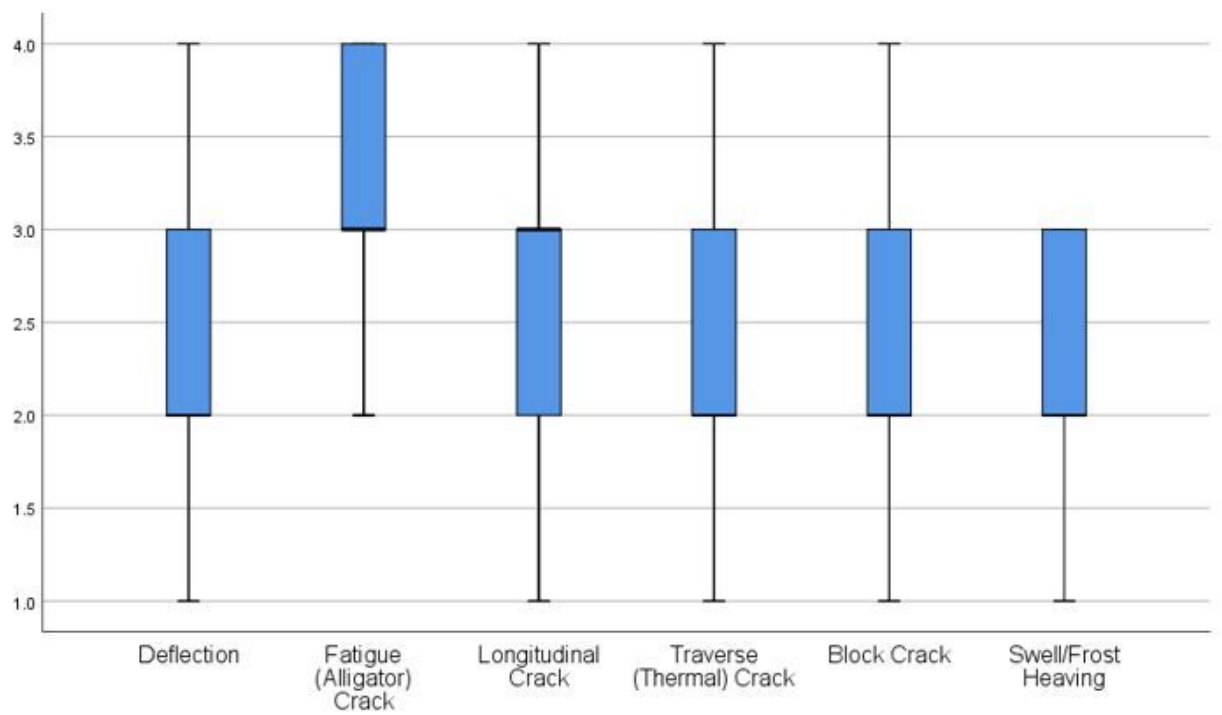

Figure 4

Boxplot assessment for structural indicators

Figure 5

Boxplot assessment for functional indicators 


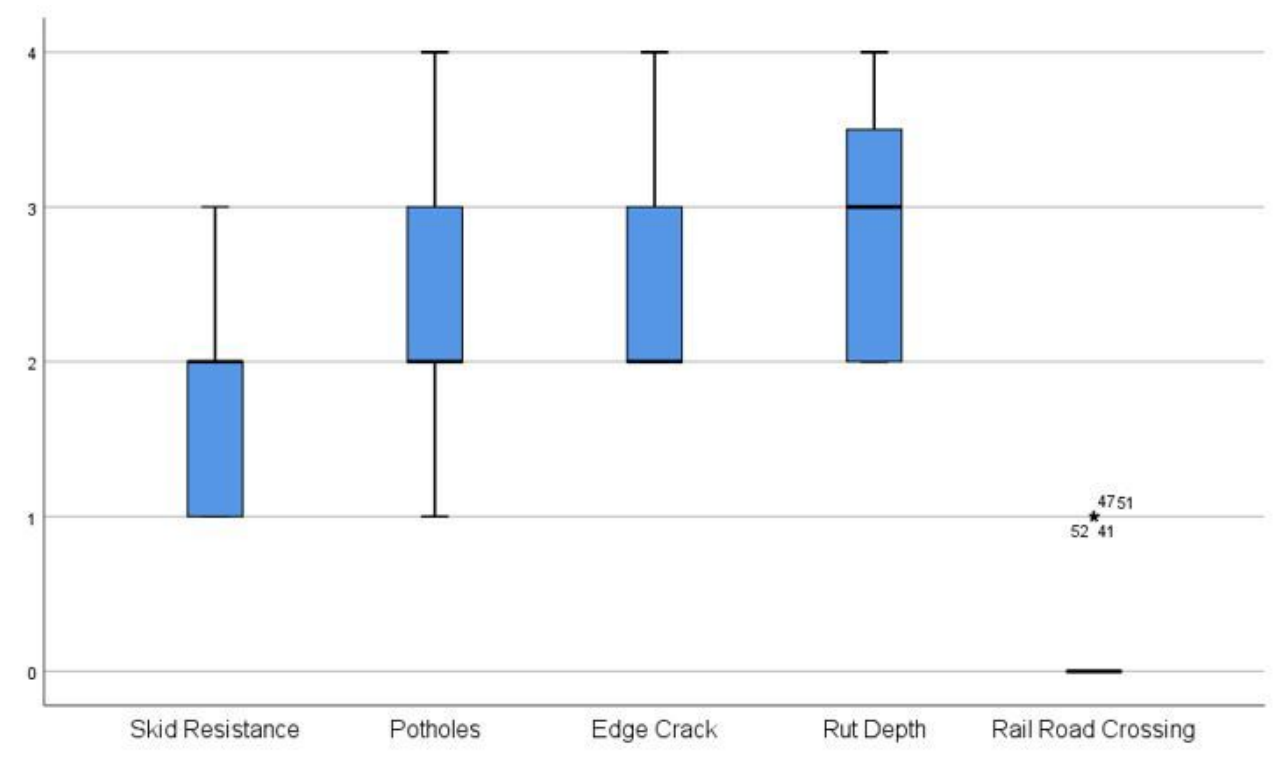

Figure 6

Boxplot assessment for safety indicators

Figure 7

Boxplot assessment for serviceability indicators

Figure 8

PMS Framework 